Scientific review article

Received: 2.2.2017

Approved: 1.3.2017.

\title{
ANALYSIS \\ OF PUBLIC-PRIVATE PARTNERSHIP PROJECTS IN SERBIA
}

The concept of public-private partnership (PPP) (Public-Private Partnership - PPP) in the last few decades have become a very desirable way of financing the construction, maintenance and operation of public infrastructure and provision of public services, activities that traditionally belong to the public sector. As there is constant need for improvement of public services and lack of funds, PPP emerges as a possible wayof solving the problem of financing the development. In countries in transition, such as Serbia, especially during periods of recession and fiscal restrictions, PPP takes onor at least it should gain in importance. Will the concept of PPP be used to the desired extent depends on a number of very different factors such as: the capacity of professional sector, political environment, economic policy, market conditions, macroeconomic stability, institutional framework, the quality of legal system. The impact of some of these factors on PPP will be analyzed in this paper with more attention paid to the legal system which represents a backbone for successful partnerships.

Keywords: Public Private Partnerships (PPP), Western Balkan Countries, project, economy, development

\footnotetext{
* Associate Professor Aleksandar M. Damnjanović, $\mathrm{PhD}$ Faculty for Economics "Dositej”, Belgrade, Serbia;

Center for Public-Private Partnership, Belgrade, Serbia; email: adm.tfc@gmail.com

** Prof. Milomir Minić, PhD

The Faculty of Law, John Naisbitt University, Belgrade, Serbia email: mminic@naisbitt.edu.rs

*** Assistant Professor Svetislav Milovanović, $\mathrm{PhD}$ Faculty for Economics "Dositej”, Belgrade, Serbia; Center for Public-Private Partnership, Belgrade, Serbia; email: sv.milovanovic@institution.rs
} 


\section{Introduction}

Public-private partnerships (PPP) standfor cooperation between the public and private sectors. The term public-private partnership first appeared in the USA during the fifties of the last century in education programs about the possibilities of cooperation between the public and private sectors. Later, during the sixties widely used also in the United States, the term continued its practice. It is interesting that, during the XVIII and XIX centuries in the UK, small groups of entrepreneurs joined in order to renew and repair local roads, or it was done by borrowing from private investors.

After that, the invested moneyreturned to them through charging tolls for a certain period. Most of London's bridges, as well as the Brooklyn Bridge in New York were maintained or built up from private funds. In France, the construction of the Channel with the capital of private sector began during the $17^{\text {th }}$ century.

The economic objective of public-private partnerships is that each party provides services within its means and knowledge. The interests of the public and private partners are complementary because each side achieves its interests by such an arrangement. Most of the authors state that the 'golden rule' of PPP is as follows: when redistributing the risk, in principle, the rule is that the success of the PPP project assumes that the risk is directed at the participant (party) who has the ability and interest to eliminate or reduce the probability of occurrence of the risk or eliminate its consequences; also has resources (technological, economic, expert, political) to, as soon as possible and with the least possible costs, respond to the occurrence or risk or the emergence of a particular risk.

In financial institutions, for example development banks, which usuallyprovide financial support and monitor these projects, efficient risk sharing is a crucial issue and the subject of analysis. The PPP is a model which significantly brings into balancerisks and rewards between public and private partners. This does not mean that all the parties in the model participate on an equal basis, but that each party's involvement depends on its quality and performance. An important aspect of PPP is its principle of conceptual transparency, which must be clearly limited in practice by means of a special regulation, on a long term basis.

\section{Literature review}

The literature covers a wide range of discussions on various issues ofintroduction and implementation of PPP at the national and global level. A significant research carried out at national level covers the following countries: Malaysia, AbdulAziz ${ }^{1}$ introduced the control mechanisms ofthe PPP during thebuild housing units;

Abdul-Aziz, A.-R. (2012): Control mechanisms exercised in Malaysian housing publicprivate partnerships. Construction Management and Economics, 30(1), 37-55. 
Indonesia, Abednego\&Ogunlana ${ }^{2}$ presented an analysis of risk allocation in order to enhanceproject management; Ghana, the Ameyaw\&Chan ${ }^{3}$ also took into account the allocation of risks applicable to projects of water supply; United Arab Emirates, Dulaimi et al. ${ }^{4}$ made an overview of how the execution of PPP projects to that country; Portugal, several publications by Franco\&Quintela;Silvestre; Rodrigues\&Sangster ${ }^{567}$ covered the issues of thetourism sector and business; Australia, the authors Jefferies\&McGeorge; Keating\&Keating ${ }^{89}$ were concerned with matters of procurement of funds for the development of public infrastructure through PPP projects. InDenmark, Koch\&Buser ${ }^{10}$ presented the concept of meta-management as institutionalized framework; the definition of non-financial determinants for PPP in Europe was the subject of the paper by Mota\&Moreira ${ }^{11}$. Pârvu\&Voicu-Olteanu ${ }^{12}$

2 Abednego, M. P., \&Ogunlana, S. O. (2006): Good project governance for proper risk allocation in public-private partnerships in Indonesia. International Journal of Project Management, 24(7), 622-634. Ahmadjian, C. J., \&Collura, J. (2012): Evaluating public-private partnership organizational alternatives for existing toll roads. Journal of Management in Engineering, 28(2), 114-119.

3 Ameyaw, E. E., \& Chan, A. P. C. (2015). Risk allocation in public-private partnership water supply projects in Ghana. Construction Management and Economics, 33(3), 187-208. Amponsah, C. T., \& Forbes, J. L. (2012). Public-private partnerships: Critical factors for procurement of capital projects. Proceedings of Institution of Civil Engineers: Management, Procurement and Law, 165(4), 211-221.

4 Dulaimi, M. F., Alhashemi, M., Ling, F. Y. Y., \&Kumaraswamy, M. (2010): The execution of public-private partnership projects in the UAE (United Arab Emirates). Construction Management and Economics, 28(4), 393-402.

5 Franco, M., \&Quintela, F. (2013): Public-private partnerships in the ecotourism sector: A Portuguese case study. World Review of Entrepreneurship, Management and Sustainable Development, 9(3), 365-392.

6 Silvestre, H. C. (2012): Public-private partnership and corporate public sector organizations: Alternative ways to increase social performance in the Portuguese water sector? Utilities Policy, 22, 41-49.

7 Rodrigues, L. L., \& Sangster, A. (2012): "Public-private partnerships": The Portuguese General Company of Pernambuco and Paraíba (1759). Business History, 54(7), 1142-1165.

8 Jefferies, M., \&McGeorge, W. D. (2009): Using public-private partnerships (PPPs) to procure social infrastructure in Australia. Engineering, Construction and Architectural Management, 16(5), 415-437.

$9 \quad$ Keating, B. \& Keating, M. . (2013): Private firms, public entities, and microeconomic incentives: Public private partnerships (PPPs) in Australia and the USA. International Journal of Organizational Analysis, 21(2), 176-197.

10 Koch, C., \&Buser, M. (2006): Emerging metagovernance as an institutional framework for public private partnership networks in Denmark. International Journal of Project Management, 24(7), 548-556.

11 Mota, J., \& Moreira, A. C. (2015): The importance of non-financial determinants on publicprivate partnerships in Europe. International Journal of Project Management, 33(7), 1563-1575.

12 Pârvu, D. \&Voicu-Olteanu, C. (2009): Advantages and limitations of the public private partnerships and the possibility of using them in Romania. Transylvanian Review of 
analyzed the actual use of value, benefits and limitations of public-private partnerships in Romania, Greece, Roumboutsos\&Anagnostopoulos ${ }^{13}$ ranked the risks and presented the best ways to allocate risks in projects; Sweden, Ruuska\&Teigland ${ }^{14}$ discussed the impact of the collective commitment to the implementation of the project as the basis of success; China, Shen et al. ${ }^{15}$ analyzed the impact of PPPs on risk management in public sector projects in Hong Kong.

Authors Yuan J. et al. and Yuan J.-F. et al. ${ }^{1617}$ analyzed the build housing units inthe public sector and urban transport systems. Zhao ${ }^{18}$ presented the results of the renewal of architecture and historical importance in the city of Dali,Belgium, the authors van den Hurk\&Verhoest ${ }^{19}$ analyzed project management in the field of sport, in the United States, Wang ${ }^{20}$ examined the evolution of the PPP model in American development projects, Wojewnik-Filipkowska\&Trojanowski ${ }^{21}$ presented the principles of PPP financing in Poland, Grimsey\&Lewis ${ }^{22}$ examined the principles of risk assessment tests on the case of the factory for waste water treatment in Scotland.

\section{Administrative Sciences, (27 E), 189-198.}

13 Roumboutsos, A., \&Anagnostopoulos, K. P. (2008). Public private partnership projects in Greece: Risk ranking and preferred risk allocation. Construction Management and Economics, 26(7), 751-763.

14 Ruuska, I., \&Teigland, R. (2009): Ensuring project success through collective competence and creative conflict in public-private partnerships - A case study of Bygga Villa, a Swedish triple helix e-government initiative. International Journal of Project Management, 27(4), 323-334.

15 Shen, L.-Y., Platten, A., \& Deng, X. P. (2006): Role of public private partnerships to manage risks in public sector projects in Hong Kong. International Journal of Project Management, 24(7), 587-594.

16 Yuan, J., Guang, M., Wang, X., Li, Q. \&Skibniewski, M. J. (2012): Quantitative SWOT analysis of public housing delivery by public-private partnerships in China based on the perspective of the public sector. Journal of Management in Engineering, 28(4), 407-420.

17 Yuan, J.-F., Skibniewski, M. J., Li, Q., \& Shan, J. (2010): The driving factors of China's public-private partnership projects in metropolitan transport systems: Public sector's viewpoint. Journal of Civil Engineering and Management, 16(1), 5-18.

18 Zhao, Y. (2015): “Chinas leading historical and cultural city': Branding Dali City through public-private partnerships in Bai architecture revitalization. Cities, 49, 106-112.

19 van den Hurk, M., \&Verhoest, K. (2015): The governance of public-private partnerships in sports infrastructure: Interfering complexities in Belgium. International Journal of Project Management, 33(1), 201-211.

20 Wang, Y. (2015): Evolution of public-private partnership models in American toll road development: Learning based on public institutions' risk management. International Journal of Project Management, 33(3), 684-696.

21 Wojewnik-Filipkowska, A., \&Trojanowski, D. (2013): Principles of public-private partnership financing - Polish experience. Journal of Property Investment and Finance, 31(4), 329-344.

22 Grimsey, D., \&Lewis, M. K. (2002): Evaluating the risks of public private partnerships for infrastructure projects. International Journal of Project Management, 20(2), 107-118. 
Bloomfield ${ }^{23}$ in his paper explores some of the practical obstacles to achieving competitiveness, fair sharing of risk, and adequate transparency in innovative long-term contracts. Carbonara et al. ${ }^{24}$ developed a new mechanism for setting the guaranteed level of income that is provided by the Government, which balances the needs of the profitability in the private sector and the fiscal interests of the management in the public sector using the concept of equality for structuring the minimum revenue guaranteed.

\section{Types of PPP}

The range of possibilities in the provision of public infrastructure and public services, depending on the subjects, is large. It ranges from the direct providing of services by the state only to privatization when the state transfers all the responsibilities, risks and rewards of providing servicesto private sector. Within this spectrum, public-private partnerships can be classified into several forms depending on the level of involvement of the public and private sectors and allocation of risk.

Besides, there isa series of models of public-private partnership (PPP), which allocate responsibilities and risks between public and private partners in different ways. The modalities of public-private partnerships that are most frequent in practice to describe typical partnership agreements, and which are recognized by many authors, are given below in alphabetical order:

1) $\mathrm{BBO}$ (Buy-Build-Operate): The transfer of public assets to the private entity, usually under a contract that funds the need to be upgraded and guided during this period. Public control is performed through a contract at the time of transmission (in this case there is a transfer of public assets to the private partner or mixed entity).

2) BLOT (Build-Lease-Operate-Transfer): Private entity receivesa franchise funds, designs, manages, builds or rents a facility (charging user costs) for the period of the lease, instead of paying the rent.

3) BOO (Build-Own-Operate): The private sector finances, builds, owns and manages the institution or service indefinitely. Public restrictions are specified in the original contract and the permanent regulatory body.

4) BOOT (Build-Own-Operate-Transfer): Private entity receives franchise funds, designs, builds and manages the facility (charging user costs) for a certain period, whereuponownership is transferred to public sector.

23 Bloomfield, P. (2006): The challenging business of long-term public-private partnerships: Reflections on local experience. Public Administration Review, 66(3), 400-411.

24 Carbonara, N., Costantino, N., \& Pellegrino, R. (2014): Revenue guarantee in public-private partnerships: a fair risk allocation model. Construction Management and Economics, 32(4), 403-415. 
5) BOT (Build-Operate-Transfer): Private sector designs, finances and constructs a new facility under long-term concession projects and manages the facility for the duration of the concession, whereupon the ownershipis transferred topublic sector unless it is transferred at the end of building.

6) DB (Design-Build): Private sector designs and builds infrastructure to meet public sector performance specifications, often at a fixed price at a turnkey, so that the risk of exceeding costsis transferred to private sector. Most often fixed price is set, cost risk is mainly on a private partner (DB projects are often considered not to be within the spectrum of public-private partnerships).

7) DBFO (Design-Build-Finance-Operate): Private sector designs, finances and constructs a new facility under a long-term rental, and manages the facility during the rental period. Private partner transfers the new facility to public sector at the end of the rental period.

8) FO (Finance Only): Private entity, usually a company for funding, finances the project directly or uses various mechanisms such as long-term lease or bond issue.

9) O\&M (Operation \& Maintenance Contract): Family manager, under contract, manages public funds for a certain period. The ownership of the means remains in public sector.

10) OL (Operation License): Family Head obtains a license or the right to manage public services, usually for a limited period of time. This model is widely used in IT projects.

\section{Private Public Partnership projects in Serbia}

Before the PPP Law came into force only a few documented PPP projects had been implemented in Serbia. At the central government level a large number of userfinanced concessionswereapproved, but many were weaned. The most important project was the proposed concession Horgos-Pozega. The length of $300 \mathrm{~km}$ was supposed to connect the city of Pozega, Western Serbia to border crossing with Hungary Horgos. Instead of making a capital investment, the government sent an invitation to tender in 2005. The contract was awarded to the Spanish-Austrian consortium and signed in 2007. However, the financial agreement was never reached and private partners withdrew, so the arbitration procedure was initiated in 2008.

At the local administrative level, a number of contracts were signed for public services, mainly in the sectors of waste management and public transport. Information on these contracts does not contain a lot of detailsand therefore is not widely described. After the adoption of the PPP Law, nine proposals were submitted to the PPP Committee for approval. PPP Committee approved seven - all submitted by local authorities. 
The list of approved and submitted projects is given below:

- Renovation and expansion of existing optical telecommunication network in Novi Sad;

- The construction, financing and operation of the internal ports and roads on the Danube in Apatin;

- Acquisition of necessities of public transport services in Loznica;

- Design, construction, financing and operation of public car parks in Sabac;

- Construction of factories for the processing of biomass (energy) in Zrenjanin;

- Acquisition of necessities of public transport services in Topola; and

- Acquisition of necessities of public transport services in Srbobran.

Only the project of renovation and expansion of optical telecommunication network in Novi Sad was implemented by the deadline. Other projects are still in the stage of preparation or procurement. The central government and the autonomous province of Vojvodinahave recently signed cooperation protocol for the preparation of the project of constructing the highway Novi Sad-Ruma. The project value of 180 million euros can be implemented according to the PPP scheme. Table 1 provides an overview of just some of the potential and approved projects on the territory of the Republic of Serbia in the period 2008-2015.

Serbia is also one of the largest recipients of EU funding among all WBC with 200 million euros a year EU Info Centre ${ }^{25}$. Since 2000 the EU has implemented projects in transport infrastructure, health, water quality and air quality, solid waste treatment, and administrative legal reforms to provide better services for citizens.

The current legal framework allows for different types of cooperation between public and private sectors - the contract on entrusting public utilities, to the establishment of institutional partnerships when setting up a new legal entity. The Republic of Serbia, autonomous provinces and local government units can entrust the provision of municipal services to private entities (conducting commercial activities - companies), other legal entities (non-profit organizations) and natural persons (entrepreneurs). In order for these entities to perform the required activities, the public entity must entrust them with performance of these activities through a contract, which defines the rights and obligations related to the performance of activities of general interest (contractual PPPs).

Public-private partnership (PPP), according to Article 7 of the Law is a longterm cooperation between public and private partners to ensure funding, construction, reconstruction, management or maintenance of infrastructure and other public facilities, and the provision of services of public interest, which may be contractual or institutional. The law specified the essential elements of the PPP which, inter alia, relate to:

25 EU Info Centre, GROWING TOGETHER, Most Successful EU Funded Projects in Serbia, EU Info Centre in Belgrade, January 2015, pp. 1-48. 
1) the object of the PPP, which cannot be solely commercial use of commonly used goods or other property;

2) forms of PPP which may be:

a) contract - mutual rights and obligations in the implementation of the PPP project, with or without elements of concession, the parties executing the public contract, (the contents prescribed in Article 46). Public contract granting a concession shall regulate the rights and obligations of the grantor and the concessionaire in accordance with the provisions of this Law and provisions of special regulations governing the area that is the subject of the concession.

The issues relating to public contracts, which are not specifically regulated by this law, are regulated by the provisions of the law regulating contracts and torts. On 8th November 2016, the PPP commission approved 32 public-private partnerships out of 48 proposals in total; the PPP commission gave a positive opinion on the following approved projects, with or without elements of concession, in Serbia, as given in Table 1:

Table 1 List of theapproved projects in Serbia in period 2014-2016

1. Name: Passenger transport - Srbobran

Description: Proposal for Concession Act of entrustment of performing activities urbansuburban passenger transport in the municipality of Srbobran;

2. Name: Passenger transport - Niš

Description: Proposal of a public-private partnership for the performance of public utilities urban and suburban passenger transportation in the city of Nis;

3. Name: Passenger transport - Jagodina

Description: Proposal for Concession Act of entrustment of performing activities urbansuburban transport of passengers on the territory of Jagodina;

4. Name: Sewage network

Description: Proposal of a public-private partnership for financing, construction, operation and maintenance of the sewerage network in the municipality of StaraPazova;

5. Name: Replacement of boilers - Niš

Description: Proposal of a public-private partnership filed by the city of Nis, which proposes replacing boilers on fuel oil and coal-fired boilers as well as wood biomass boilers (pellet) in schools and preschools of the city of Nis with the delivery of thermal energy;

6. Name: Municipal waste - Topola

Description: Proposal for the concession document entrusting the performance of utility activities of collection and transport of municipal waste from rural areas of the municipality of Topola; 
7. Name: Municipal waste - Žagubica

Description: Proposal for the concession document entrusting the performance of utility activities of collection and transport of municipal waste from the municipality of Žagubica;

8. Name: Passenger transport - Šabac

Description: Proposal for Concession Act for municipal activities of urban and suburban passenger transportation in the city of Sabac;

9. Name: High-way E-763, Belgrade-Požega

Description: Proposal for Concession Act with the analysis of financial-economic effects of giving concessions to the highway E-763 Belgrade-Pozega;

10. Name: Heat energy - Batočina

Description: Proposal for Concession Act which proposes entrusting production and distribution of thermal energy in the municipality of Batočina;

11. Name: Waste management - Keleš

Description: Proposal for Concession Act which proposes the construction of a regional waste management center Keleš;

12. Name: Public lighting - Topola

Description: Proposal of a public-private partnership that proposes conducting public utilities of reconstruction, rationalization and maintenance of public lighting in the municipality of Topola;

13. Name: Public lighting - Sečanj

Description: Proposal of a public-private partnership which proposes replacing the existing lamps of public lighting with energy saving "LED" lights in the area of streets, parks, promenades, public areas, external decorative lighting of public buildings and monuments in the villages of the municipality;

14. Name: Passenger transport - Negotin

Description: Proposal for Concession Act which proposes entrusting the performance of suburban passenger transport in the municipality of Negotin;

15. Name: Heat energy - Grocka

Description: Proposal of a public-private partnership for entrusting the performance of utility activities of collection, transport and disposal of municipal waste and the production and distribution of thermal energy in the territory ofGocka;

16. Name: Passenger transport - Paraćin

Description: Proposal for Concession Act which proposes entrusting the performance of suburban passenger transportation in the municipality of Paracin;

17. Name: Public lighting - Vrbas

Description: Proposal of a public-private partnership that proposes reconstruction of a part of the system of public lighting in the municipality of Vrbas;

18. Name: Energy production - Vrbas

Description: Proposal of a public-private partnership for the production of heat and electricity using renewable energy sources in the municipality of Vrbas; 
19. Name: Replacement of boilers - Pirot

Description: Proposal of a public-private partnership which proposes replacing of the existing fuel oil boilers to biomass boilers and contract delivery of thermal energy in the facilities of Dairy School "DrObrenPajic," elementary school "SvetiSava”, elementary school "DusanRadovic" elementary school „8. September", in the municipality of Pirot;

20. Name: Municipal waste - Belgrade

Description: Proposal of a public-private partnership has been submitted by the city of Belgrade, which proposes treatment and disposal of municipal waste;

21. Name: Passenger transport - Belgrade

Description: Proposal of a public-private partnership for the performance of public utilities of public transport of passengers in the city of Belgrade;

22. Name: Passenger transport - Kanjiža

Description: Proposal for Concession Act of entrustment of urban-suburban passenger transport in the municipality of Kanjiža;

23. Name: Public lighting - Vranje

Description: Proposal of a public-private partnership for reconstruction of a part of the public lighting in the city of Vranje;

24. Name: Road infrastructure - StaraPazova

Description: Proposal of a public-private partnership for financing, construction and maintenance of local road infrastructure in the municipality of StaraPazova;

25. Name: Public lighting - Varvarin

Description: Proposal of a public-private partnership for reconstruction of a part of the public lighting in the municipality of Varvarin;

26. Name: Public lighting - Žabalj

Description: Proposal of a public-private partnership for reconstruction, rationalization and maintenance of public lighting in the villages of the municipality ofŽabalj;

27. Name: Water supply - Brus

Description: Proposal of a public-private partnership submitted by JKP „Rasina” Brus proposing the construction of the main pipeline for water supply of the municipality ofBrus and construction of a small hydropower plant;

28. Name: Public lighting - Ada

Description: Proposal of a public-private partnership for modernization, rationalization and maintenance of public lighting in the villages of the municipality of Ada;

29. Name: Public lighting - Beočin

Description: Proposal of a public-private partnership for modernization, rationalization and maintenance of public lighting in the villages of the municipality ofBeočin;

30. Name: Passenger transport - Belgrade

Description: Proposal of a public-private partnership for the performance of suburban and local transport of passengers in the city of Belgrade; 
31. Name: Public lighting - Plandište

Description: Proposal of a public-private partnership for replacement of the existing public lighting lamps with energy-saving „LED” lights in the area of streets, parks, promenades, public areas and exterior decorative lighting of public buildings in the settlements of the municipality of Plandište;

32. Name: Urban equipment - Belgrade

Description: The Proposal of Concession Act for financing of the purchase and handover to the city of Belgrade, for the purpose of installation, of street furniture elements that cannot be used commercially and financing of the purchase, installation, maintenance and commercial use of certain street furniture elements that can be used commercially.

Figure 1 gives a comparative view of the amount of investments in Serbia by donor countries for the period from 2000 to 2015, where we can see that investments from European funds are by far the largest amounting to 3 billion. The second-ranking according to its investments were the United States with 679 million euros. The most notable fact is that the majority of investment comes from Europe, while Serbia has also the support of large and technologically developed countries such as Germany with 350 million euros and China and Japan, total investment of which is about 120 million for the reference period.

Figure 1 Donors to Serbia for the period 2000-2015 in millions of euro

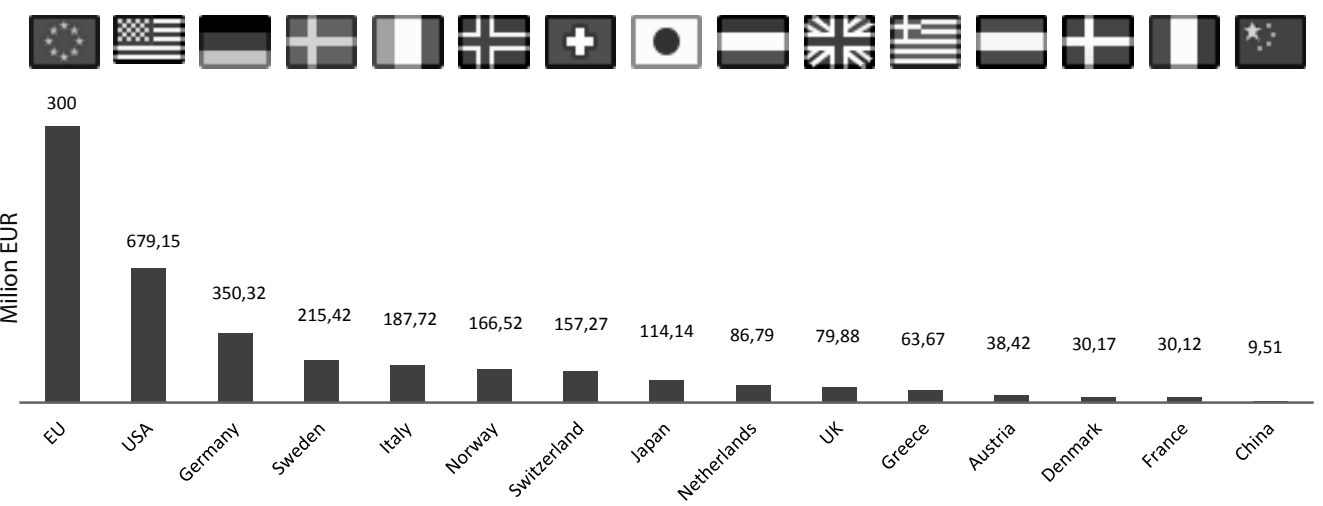

Source: ${ }^{26}$

26 The Delegation of the European Union to the Republic of Serbia http://europa.rs/ eu-assistance-to-serbia/ 


\section{Conclusion}

The concept of public-private partnerships in the last few decades has become a preferred way of financing construction, maintenance and operation of public infrastructure and the provision of public services, activities that traditionally belong to public sector. The need for constant improvement of public services and lack of funds, have led to establishing PPP model as a way of solving the problem of financing development. In countries in transition, such as Serbia, especially during periods of recession and fiscal restrictions, PPP takes on or should at least gain in importance. Will the PPP concept be used to the desired extent depends on a number of very different factors such as: the capacity of public sector, political environment, economic policy, market conditions, macroeconomic stability, institutional framework, the quality of the legal system.

In the Republic of Serbia there are underused possibilities of applying the concept of public-private partnerships for capital projects such as highways, tunnels, bridges, railways, airports, ports, and the underground. The fact that there are problems and lack of efficiency in the implementation of initiated projects for which the country provided funds from international sources indicates that lack of funds is not the only problem. Obviously there are many reasons for decision makers in public sector why they are reluctant to enter into PPP arrangements. In the context of this study, the causes that lead to this were analyzed. The reasons why public sector must use PPP concept more, are reflected not only in the lack of budget funds, but also in the fact that private sector participation ensures rationalization of projects, ranking them by priority and effects. 


\section{References}

- Abdul-Aziz, A.-R. (2012): Control mechanisms exercised in Malaysian housing public-private partnerships. Construction Management and Economics, 30(1), 37-55.

- $\quad$ Abednego, M. P., \&Ogunlana, S. O. (2006): Good project governance for proper risk allocation in public-private partnerships in Indonesia. International Journal of Project Management, 24(7), 622-634. Ahmadjian, C. J., \&Collura, J. (2012): Evaluating public-private partnership organizational alternatives for existing toll roads. Journal of Management in Engineering, 28(2), 114-119.

- Ameyaw, E. E., \& Chan, A. P. C. (2015): Risk allocation in public-private partnership water supply projects in Ghana. Construction Management and Economics, 33(3), 187-208. Amponsah, C. T., \& Forbes, J. L. (2012): Public-private partnerships: Critical factors for procurement of capital projects. Proceedings of Institution of Civil Engineers: Management, Procurement and Law, 165(4), 211-221.

- Dulaimi, M. F.,Alhashemi, M., Ling, F. Y. Y., \&Kumaraswamy, M. (2010): The execution of public-private partnership projects in the UAE (United Arab Emirates). Construction Management and Economics, 28(4), 393-402.

- Franco, M., \&Quintela, F. (2013): Public-private partnerships in the ecotourism sector: A Portuguese case study. World Review of Entrepreneurship, Management and Sustainable Development, 9(3), 365-392.

- Silvestre, H. C. (2012): Public-private partnership and corporate public sector organizations: Alternative ways to increase social performance in the Portuguese water sector? Utilities Policy, 22, 41-49.

- Rodrigues, L. L., \& Sangster, A. (2012): "Public-private partnerships": The Portuguese General Company of Pernambuco and Paraíba (1759): Business History, 54(7), 1142-1165.

- Jefferies, M., \&McGeorge, W. D. (2009): Using public-private partnerships (PPPs) to procure social infrastructure in Australia. Engineering, Construction and Architectural Management, 16(5), 415-437.

- Keating, B. \& Keating, M. (2013): Private firms, public entities, and microeconomic incentives: Public private partnerships (PPPs) in Australia and the USA. International Journal of Organizational Analysis, 21(2), 176-197.

- Koch, C., \&Buser, M. (2006): Emerging metagovernance as an institutional framework for public private partnership networks in Denmark. International Journal of Project Management, 24(7), 548-556.

- Mota, J., \& Moreira, A. C. b. (2015): The importance of non-financial determinants on public-private partnerships in Europe. International Journal of Project Management, 33(7), 1563-1575.

- Pârvu, D. \&Voicu-Olteanu, C. . (2009): Advantages and limitations of the public private partnerships and the possibility of using them in Romania. Transylvanian Review of Administrative Sciences, (27 E), 189-198. 
- $\quad$ Roumboutsos, A., \&Anagnostopoulos, K. P. (2008): Public private partnership projects in Greece: Risk ranking and preferred risk allocation. Construction Management and Economics, 26(7), 751-763.

- Ruuska, I., \&Teigland, R. (2009): Ensuring project success through collective competence and creative conflict in public-private partnerships - A case study of Bygga Villa, a Swedish triple helix e-government initiative. International Journal of Project Management, 27(4), 323-334.

- Shen, L.-Y., Platten, A.,\& Deng, X. P. . (2006): Role of public private partnerships to manage risks in public sector projects in Hong Kong. International Journal of Project Management, 24(7), 587-594.

- Yuan, J., Guang, M., Wang, X., Li, Q. .e, \&Skibniewski, M. J. . (2012): Quantitative SWOT analysis of public housing delivery by public-private partnerships in China based on the perspective of the public sector. Journal of Management in Engineering, 28(4), 407-420.

- Yuan, J.-F. b, Skibniewski, M. J., Li, Q.,\& Shan, J. . (2010): The driving factors of China's public-private partnership projects in metropolitan transport systems: Public sector's viewpoint. Journal of Civil Engineering and Management, 16(1), 5-18.

- Zhao, Y. (2015). “China’s leading historical and cultural city”: Branding Dali City through public-private partnerships in Bai architecture revitalization. Cities, 49, $106-112$.

- $\quad$ van den Hurk, M., \&Verhoest, K. (2015): The governance of public-private partnerships in sports infrastructure: Interfering complexities in Belgium. International Journal of Project Management, 33(1), 201-211.

- Wang, Y. (2015): Evolution of public-private partnership models in American toll road development: Learning based on public institutions' risk management. International Journal of Project Management, 33(3), 684-696.

- Wojewnik-Filipkowska, A., \&Trojanowski, D. (2013): Principles of public-private partnership financing - Polish experience. Journal of Property Investment and Finance, 31(4), 329-344.

- Grimsey, D., \& Lewis, M. K. (2002): Evaluating the risks of public private partnerships for infrastructure projects. International Journal of Project Management, 20(2), 107-118.

- Bloomfield, P. (2006): The challenging business of long-term public-private partnerships: Reflections on local experience. Public Administration Review, 66(3), 400-411.

- Carbonara, N., Costantino, N., \& Pellegrino, R. (2014): Revenue guarantee in public-private partnerships: a fair risk allocation model. Construction Management and Economics, 32(4), 403-415.

- The Delegation of the European Union to the Republic of Serbia http://europa.rs/ eu-assistance-to-serbia/ 
Dr Aleksandar M. Damnjanović, vanredni profesor

Visoka škola akademskih studija „Dositej“, Beograd;

Centar za javno - privatno partnerstvo, Beograd

Prof. Dr Milomir Minić

Pravni fakultet, Univerzitet „Džon Nezbit”, Beograd

Dr Svetislav Milovanović, Docent

Visoka škola akademskih studija „Dositej“, Beograd;

Centar za javno - privatno partnerstvo, Beograd

\section{ANALIZA PROJEKATA \\ JAVNO-PRIVATNOG PARTNERSTVA \\ U SRBIJI}

Koncept javno-privatnog partnerstva (JPP) (Javno-privatno partnerstvo - JPP) u poslednjih nekoliko decenija postali su veoma poželjan način finansiranja izgradnje, održavanja i funkcionisanja javne infrastrukture i pružanja javnih usluga, aktivnost koje tradicionalno pripadaju u javnom sektoru. Potreba za stalnim poboljšanjem javnih usluga i nedostatka sredstava, tako da je JPP mogući način rešavanja problema razvoja finansiranja. U zemljama u tranziciji, poput Srbije, posebno tokom perioda recesije $i$ fiskalnih ograničenja, JPP dobija ili bi bar trebalo da dobije na značaju. Da li će to biti koncept JPP koji će se koristiti u željenom meri zavisi od velikog broja veoma različitih faktora, kao što su: karakteristike privatnog sektora, političkog okruženja, ekonomske politike, tržišnih uslova, makroekonomske stabilnosti, institucionalnog okvira, kvalitet pravnog sistema. Uticaj nekih od ovih faktora na JPP će se analizirati u ovom radu sa posebnom pažnjom na pravni aspekt koji prestavlja osnovu uspešnog partnerstva.

Ključne reči: Javno-privatno partnerstvo (JPP), zemlje Zapadnog Balkana, projekat, privreda, razvoj 